\title{
Handling Practices During Distribution of Kinnow-Mandarins (Citrus nobilis x Citrus deliciosa) Used for Preparation of Fresh-Squeezed Juices and their Effects on Microbiological Safety
}

\author{
M. Ghosh, A. Ganguli* and M. Kumar \\ Department of Biotechnology and Environmental Sciences, \\ Thapar Institute of Engineering and Technology, \\ Patiala-147004, Punjab, India \\ تأثير طرق توزيع اليوسفي نوع كينو لغرض تحضير العصير الطازج على السلامة من الأحياء المجهرية \\ أ. جانجولي
}

الخلاصة: إن الهدف من هذه الدراسة هو لتقييم سلامة اليوسفي من الإصابة بالأحياء المجعرية عند تحضيره كعصير من

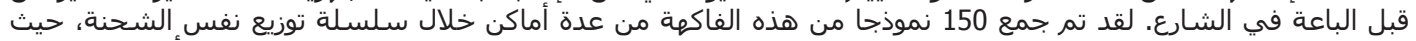

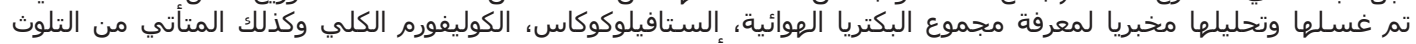

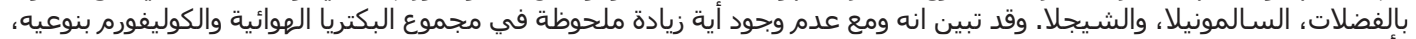

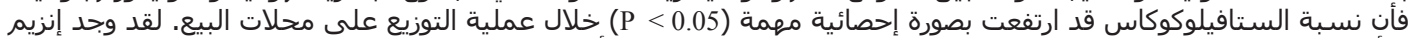

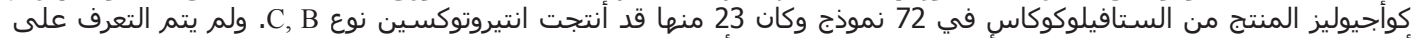

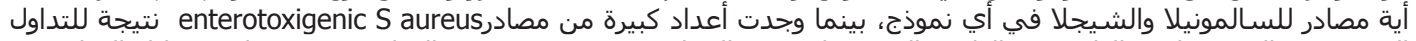

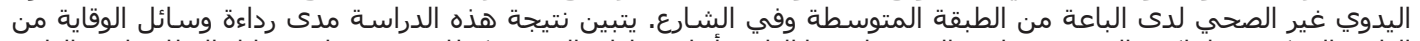

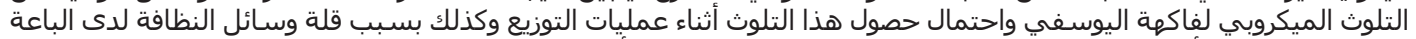

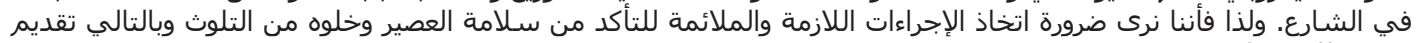
عصير طازج سليم صحي.

ABSTRACT: The objective of this study was to assess the microbiological safety of Kinnow-mandarins (Citrus nobilis $\mathrm{X}$ Citrus deliciosa) used for preparation of fresh squeezed juices by street vendors. One hundred and fifty Kinnow mandarin samples were collected from different points in the distribution chain from the same lot, washed and aliquots of the wash samples were analyzed for total aerobes, Staphylococcus, total and fecal coliforms, Salmonella and Shigella. Although, there was no notable increase in the total aerobic, total or fecal coliform counts, total staphylococcal counts increased significantly $(\mathrm{P}<0.05)$ during distribution to street vendors; seventy-two samples from the street vendors showed the presence of coagulase positive Staphylococcus aureus, twenty-three of these produced enterotoxins B and C. Salmonella and Shigella were not detected in any of the samples. Sources of high numbers of enterotoxigenic S. aureus were traced to unhygienic manual handling by middle level buyers and by street vendors. The results of our study demonstrate the poor microbiological quality of Kinnow-mandarins, the possible entry points of contaminants in the distribution chain of these fruits and unhygienic vending practices. Appropriate intervention measures are needed to ensure safe fresh squeezed juices for consumers.

Keywords: India, distribution chain, enterotoxigenic Staphylococcus aureus.

\section{Introduction}

Outbreaks associated with fresh produce have emerged as an important public health concern and documented illnesses following consumption of raw produce or related products have been linked to bacteria, parasites and viruses (Harris et al., 2001). Fresh produce can be contaminated with pathogens not only in the field, but also from many post-harvest sources such as wash and rinse water, unhygienic human handlers, transport vehicles, cross contamination, improper storage, processing and packaging (CDR, 1991). The low sanitation standards, especially during postharvest handling, and increased consumption of raw produce and produce related products (e.g. fresh

\footnotetext{
$\overline{* \text { Corresponding author }}$
} 
squeezed fruit, vegetables juices etc) has generated heightened concerns for food safety (Chalmers et al., 2000; McMahon and Wilson, 2001; Roberts, 1997) in developing countries.

Kinnow-mandarins (Citrus nobilis X Citrus delicosa) are important products in India, especially during the months of October to March, and enjoy high consumer acceptance on account of their taste and nutritional benefits. Kinnow-mandarins are, however, preferred as fresh-squeezed juices. Although citrus juices are assumed to be safe, the consumption of unpasteurized juices may be dangerous since they could be a potential source of bacterial pathogens (Ryu et al., 1998; Uljas et al., 1998; Zhuang et al., 1995). Outbreaks of food poisoning caused by biological hazards have been traced back to the consumption of unpasteurized citrus juices (CDC, 1998).

In an earlier study Mudgil et al. (2003) reported the incidence of bacterial pathogens in street vended fresh-squeezed carrot and Kinnow-mandarin juices in Patiala, a principal city of Punjab, where approximately $94 \%$ of the population, including tourists of all ages and income groups, consume fresh squeezed juices. Although no documented outbreaks related to the consumption of juices exist in India, unofficial reports confirm that such incidents have actually increased. Contamination of produce may be minimized prior to consumption if suitable interventions are developed. However, one of the keys to the selection of appropriate intervention steps to reduce populations of pathogenic microorganisms on Kinnow-mandarins would be the identification and elimination of the sources of contamination as affected by post-harvest practices. We hypothesized the distribution chain of Kinnow-mandarins to be a major source of contamination with bacterial pathogens. The objective of this study was therefore, to assess the microbiological quality of Kinnow-mandarins at each stage of this chain up to preparation of fresh-squeezed juices by street vendors. The potential sources and vending practices contributing to such contamination were also investigated.

\section{Materials and Methods}

One hundred Kinnow-mandarin samples (whole fruits) were collected from each point of the distribution chain. All Kinnow-mandarin samples were packed individually in sterile whirl-pack bags (Fischer scientific) using sterile latex gloves. The samples were maintained on ice packs during transportation and processed within 2 hours after arrival in the laboratory. To each bag, $100 \mathrm{~mL}$ sterile $0.1 \%$ peptone water were added and samples were hand massaged for $2 \mathrm{~min}$ to dislodge the surface microbial population (Burnett and Beuchat, 2001). Part of the wash samples were further diluted in peptone water and appropriate dilutions were used for enumerating total aerobic counts, S. aureus, total and fecal coliforms. The rest of the samples were enriched for detecting Salmonella and Shigella. Aerobic plate count $\left(37^{\circ} \mathrm{C}, 24 \mathrm{~h}\right)$ was performed using plate count agar (Himedia, Mumbai, India); total coliform count was done using Violet Red bile agar (Himedia, Mumbai, India) $\left(37^{\circ} \mathrm{C}, 24 \mathrm{~h}\right)$. Presence of fecal coliforms was determined using Brilliant Green Lactose bile broth (Himedia, Mumbai, India) $\left(44.5^{\circ} \mathrm{C}\right.$, $48 \mathrm{~h}$ ), followed by confirmation of gas positive tubes using Eosin Methylene blue agar (Himedia, Mumbai, India). For enumeration of Staphylococcus aureus, 1.0 $\mathrm{ml}$ wash samples were divided among three plates $(0.3,0.3$, and $0.4 \mathrm{~mL})$ of Baird-parker agar (Himedia, Mumbai, India) supplemented with egg yolk tellurite enrichment suspension (Himedia, Mumbai, India) and spread-plated. Plates were incubated at $37^{\circ} \mathrm{C}$ for 48 hr, typical $S$. aureus colonies (jet-black, glistening, circular with clear zones) were counted and numbers calculated (log $\mathrm{cfu} / \mathrm{ml}$ or $\mathrm{g}$ ).

The isolates were identified and confirmed by biochemical tests (Brackett and Splittoessar, 1992), coagulase positive strains of $S$. aureus were tested for the production of enterotoxins using a reversed passive latex agglutination based kit (SET RPLA, Oxoid, Basingstoke, UK). Salmonella were isolated based on the protocol described by the U.S Food and Drug administration in the Bacteriological Analytical Manual; $10 \mathrm{ml}$ of wash samples were enriched in universal pre- enrichment broth for $24 \mathrm{~h}$ at $37^{\circ} \mathrm{C} ; 0.1 \mathrm{ml}$ of the preenriched culture was inoculated in semisolid Rappaport Vassiliadis Agar (Himedia, Mumbai, India) and incubated at $42{ }^{\circ} \mathrm{C}$ for $24 \mathrm{~h}$. A loop full of agar was then streaked on Xylose-Lysine Deoxycholate agar (Himedia, Mumbai, India) and incubated at 37 ${ }^{\circ} \mathrm{C}$ for 24-48 h (USFDA, 2000). Presumptive colonies were sent to National Centre for Escherichia and Salmonella, Central Research Institute, Kasauli, India for further confirmation. Shigella was selectively enriched by incubating $10 \mathrm{ml}$ peptone suspension in Shigella broth at $37^{\circ} \mathrm{C}$ for $24 \mathrm{~h}$, colonies were isolated on Xylose-Lysine-Desoxycholate agar; presumptive 
Table 1. Microbiological analysis of Kinnow-mandarins (Citrus nobilis X Citrus deliciosa) in the distribution chain. Microbial counts in each case are means of three replicates.

\begin{tabular}{lcccc}
\hline \multirow{2}{*}{ Sampling Locations* } & \multicolumn{4}{c}{ Bacterial Counts $(\mathbf{l o g} \mathbf{~ c f u} / \mathbf{g})$} \\
\cline { 2 - 5 } & $\begin{array}{c}\text { APC } \\
\text { (Range) }\end{array}$ & $\begin{array}{c}\text { TSC } \\
\text { (Range) }\end{array}$ & $\begin{array}{c}\text { TC } \\
\text { (Range) }\end{array}$ & $\begin{array}{c}\text { TFC } \\
\text { (Range) }\end{array}$ \\
\hline \multirow{2}{*}{ Central distribution site } & $4.2^{\mathrm{b}} \pm 0.5$ & $3.5^{\mathrm{b}} \pm 0.3$ & $4.8^{\mathrm{b}} \pm 0.3$ & $2.0^{\mathrm{b}} \pm 0.4$ \\
& $\left(3.3^{-5.8}\right)$ & $(3.0-5.0)$ & $(2.0-6.3)$ & $(2.2-3.0)$ \\
Middle level buyers & $4.8^{\mathrm{b}} \pm 0.4$ & $4.9^{\mathrm{b}} \pm 0.5$ & $4.8^{\mathrm{b}} \pm 0.4$ & $2.3^{\mathrm{b}} \pm 0.5$ \\
& $(4.8-5.7)$ & $(2.5-6.1)$ & $(2.0-4.9)$ & $(2.0-3.3)$ \\
Street Vendors & $4.9^{\mathrm{b}} \pm 0.5$ & $6.7^{\mathrm{b}} \pm 0.5$ & $5.2^{\mathrm{b}} \pm 0.7$ & $2.7 \pm 0.3$ \\
& $(5.0-6.6)$ & $(6.4-8.0)$ & $(2.0-6.0)$ & $(3.2-5.2)$ \\
Street Vendors & $5.9^{\mathrm{a}} \pm 0.6$ & $5.0^{\mathrm{b}} \pm 0.6$ & $3.8^{\mathrm{b}} \pm 0.4$ & $3.0^{\mathrm{b}} \pm 0.5$ \\
\hline
\end{tabular}

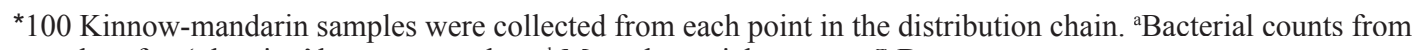
samples after 'cleaning' by street vendors. ${ }^{b}$ Mean bacterial counts \pm S.D.

colonies were streaked on TSI (Triple sugar iron media) (Himedia, Mumbai, India) and Motility agar slants (Himedia, Mumbai, India), incubated at $37^{\circ} \mathrm{C}$ and observed after 24 and $48 \mathrm{~h}$.

An unpaired students t-test was used to identify any significant differences in population proportions of total staphylococcal counts $(\alpha=0.05)$ between middle level vendors and samples hand wiped by the street vendors. Statistical analysis of data was performed with SPSS software (SPSS Inc, Chicago, Ill).

\section{Results}

In Patiala, local farmers around the city bring mandarins from farms to a central distribution site or 'mandi'. Kinnow-mandarins are purchased in bulk by middle level buyers (about ten in numbers) from the central distribution site and sold to about one hundred street vendors, who use Kinnow-mandarins for preparing fresh squeezed juices, the distribution chain through which this fruit proceeds prior to being available to consumers as fresh-squeezed juices. The total aerobic counts (Table 1) of Kinnow-mandarin samples did not differ significantly $(P>0.05)$ from its course from mandi to the carts or street vendors (4.2 to $4.88 \log \mathrm{cfu} / \mathrm{g}$ ). No significant increases of total and fecal coliforms were observed in samples during transit from the central distribution site to street vendors. Total staphylococcal counts increased significantly from $3.5 \mathrm{cfu} / \mathrm{g}$ to $6.7 \mathrm{log} \mathrm{cfu} / \mathrm{g}$. Seventytwo samples from the street vendors showed the presence of coagulase positive Staphylococcus aureus, twenty three of these produced enterotoxins B and C. Table 2 shows the handling practices adopted by the middle level buyers and street vendors. Neither Salmonella nor Shigella was detected.

Table 2. Handling practices adopted at different levels in the distribution chain of Kinnow-mandarins.

\begin{tabular}{ll}
\hline Levels in Distribution Chain & Handling Practices \\
\hline Middle level buyers & $\begin{array}{l}\text { Unhygienic storage space, remixing of damaged fruits, use of unpotable } \\
\text { water, unwashed cloths used for cleaning fruit surfaces. }\end{array}$ \\
Street vendors & $\begin{array}{l}\text { Unpotable water stored and used for multiple purposes, soaps or detergents } \\
\text { not used, use of hands for wiping fruits, dilution of juices with water, } \\
\text { frequent use of physically-damaged fruits. }\end{array}$ \\
\hline
\end{tabular}




\section{Discussion}

Prior to sampling, we identified the distribution chain for Kinnow-mandarins and studied the practices involved during different stages of handling. The distribution of Kinnow-mandarin proceeds prior to being processed for fresh squeezed juices for consumers as follows:

Central distribution site $\rightarrow$ Middle level buyers $\rightarrow$ Street vendors $\rightarrow$ Consumers

Kinnow-mandarins are usually purchased by the middle level buyers from a common central distribution site and transported by carts or vans to the shops. Manual handling at this stage is relatively low. After reloading, the fruits are remixed by these buyers according to their quality, e.g. those having minor physical damage during transport are sold at lower prices. The storage space for dumping and remixing are unhygienic and the handling personnel involved during these operations are unskilled and totally unaware of hygienic practices; the increase in total staphylococcal counts, especially coagulase positive $S$. aureus in the stages prior to procurement of Kinnow-mandarins by street vendors, may be traced to this high degree of unhygienic handling and cross contamination during remixing of the fruits. Earlier studies have shown the presence of $S$. aureus on fresh produce and ready-to-eat vegetable salads (Vishwanathan and Kaur, 2001). High numbers of coagulase positive $S$. aureus were also detected in freshly pressed carrot juice (Mudgil et al., 2003). Unhygienic handling therefore could be regarded as the primary determinant for contamination of Kinnowmandarins till this stage of distribution. Following receipt of Kinnow-mandarins, the middle-level buyers usually wiped the fruits using pieces of cloth that were moistened with water (unpotable). The same cloth was used for wiping several other fruits, the slight increase in total and fecal coliforms may be attributed to this practice. Use of contaminated cloth has been shown to aid both survival and transfer of the bacterial pathogens to foods or produces (Beuchat, 1998).

The significant increase in total staphylococcal counts $(p<0.05)$ in the same lots of Kinnow-mandarins following receipt by the street vendors, may be attributed to the practice of cleaning the outer surface of the fruits by hand. We noted that none of the street vendors used soaps for cleaning their hands either before handling the fruits or during preparation of juices; furthermore the vendors used stored water for diluting the juices. The practice of using stored water for multiple uses was found to be fairly consistent among the vendors, most of whom had limited access to clean, running water. The levels of fecal and total coliforms were reasonably high in water samples analyzed during the study (results not shown). While washing, fresh produce can reduce most microbial contamination on the surface of fruits and vegetables, reusing processing water may result in the buildup of microbial loads, including pathogens from the produce. These pathogens may be transferred to subsequent lots or batches of produce (Beuchat, 1998), in this case directly to the juices and thence to consumers.

The presence of fecal and total coliforms and high levels of coagulase positive $S$. aureus, especially enterotoxigenic $S$. aureus, in Kinnow-mandarins destined for juicing is clearly unacceptable. Although we could not detect Salmonella or Shigella spp. in the Kinnow-mandarin samples, the presence of fecal contamination implies the possible presence of enteric pathogens; the entry of such pathogens subsequently to freshly squeezed juices could be facilitated if damaged or partially damaged Kinnow-mandarins are used. In our studies approximately $87 \%$ of Kinnowmandarins procured by the street vendors were found to be partially damaged.

Overall, our study demonstrates the poor microbiological quality of Kinnow-mandarins, which are used for preparing fresh squeezed juices. The results obtained during this study can be correlated to our earlier findings (Mudgil et al., 2003) where fresh squeezed Kinnow-mandarin juices samples (18) were found to contain coagulase positive $S$. aureus, high total viable counts $(6 \mathrm{log} \mathrm{cfu} / \mathrm{ml})$ and total fecal coliform counts (5 log cfu/ml). Handling practices observed in this study during the movement of Kinnow-mandarins through the distribution chain is important in terms of safety to consumers. Recent food-borne disease outbreaks emphasize the importance of screening various vegetables and fruits, especially those that are vulnerable to contamination and those which are ready to eat, or used for products not undergoing any processing steps (Endley et al., 2003). The possible sources of contamination at various stages of distribution may be important, since adoption of proactive measures (e.g. use of running water supply, use of clean cloth or washed cloth 
for wiping fruits, blanching the fruits in hot water) could lead to reduced final contamination of Kinnowmandarins. It is crucial for government agencies to educate the vendors about food safety, hygienic practices and to set adequate standards for pathogen prevention from field to the plate.

\section{Acknowledgement}

The authors wish to thank the Coordinator, Center of Relevance and Excellence in Agro and Industrial Biotechnology, Department of Biotechnology and Environmental Sciences, for providing adequate facilities and the Technology Information and Development Council (TIFAC), Department of Science and Technology, Government of India, for financial support.

\section{References}

Beuchat, L.R. 1998. Surface decontamination of fruits and vegetables eaten raw: a review. Food safety issues.WHO/FSF/FOS98.2. Food Safety Unit. World Health Organization, Geneva.

Brackett, R.E. and D.F. Splitsstoessar. 1992. Fruits and Vegetables. In: Compendium of Methods of Microbiological Examination of Foods, C. Vanberzont and D.F. Splittstoesser (Editors), pp.919-927. APHA, Washington, D.C.

Burnett, A.B. and L.R. Beuchat. 2001. Comparison of sample preparation methods for recovering Salmonella from raw fruits, vegetables, and herbs. Journal of Food Protection 64:1459-1465.

CDC (Centers for Disease Control). 1998. Salmonella Surveillance: Annual Tabulation Summary. Atlanta, Georgia: U.S Department of Health and Human Services.

CDR. 1991. Melon associated Salmonellosis. Communicable Disease Report Weekly 36:161.

Chalmers, R., M.G. Nichols and R. Rooney. 2000. Food borne outbreaks of cyclosporiasis have arisen in North America. Is the United Kingdom at risk? Communicable Diseases to Public Health 3:50-55.

Endley, S., L. Lu, E. Vega, M. Hume and S. Pillai. 2003. Male specific coliphages as an additional contamination indicator for screening fresh carrots. Journal of Food Protection 66:88-93.

Harris, L.J., L.R. Beuchat, M.T. Kajs, T.E. Ward and C.H Taylor. 2001. Efficacy and reproducibility of a produce wash in killing Salmonella on the surface of tomatoes assessed with a proposed standard method for produce sanitizers. Journal of Food Protection 64:1477-1482.

McMahon, M.A. and I.G. Wilson. 2001. The occurrence of enteric pathogens and Aeromonas species in organic vegetables. International Journal of Food Microbiology 70:155-162.

Mudgil, S., D. Aggarwal and A. Ganguli. 2003. Microbiological analysis of street vended fresh carrot and Kinnow-mandarin juices in Patiala City, India. Internet Journal of Food Safety 3:1-3.

Roberts, R. 1997. Emerging pathogens associated with infectious diarrhea. Brazilian Journal of Infectious Diseases 1:153-176.

Ryu, J.H. and L.R. Beuchat. 1998. Influence of acid tolerance responses on survival, growth and cross protection of Escherichia coli O157:H7 in acidified media and fruit juices. International Journal of Food Microbiology 45:185-193.

Uljas, H.E. and S.C. Ingham. 1998. Survival of Escherichia coli $\mathrm{O} 157: \mathrm{H} 7$ in synthetic gastric fluid after cold and acid habituation in apple juice or trypticase soy broth acidified with hydrochloric acid or organic acid. Journal of Food Protection 61:939-947.

USFDA(United States Food and Drug Administration). 2000. Bacteriological analytical manual: AOAC International, Arlington, VA, USA.

Vishwanathan, P. and R. Kaur. 2001. Prevalence and growth of pathogens on salad vegetables, fruits and sprouts. International Journal of Hygiene Environmental Health 203:205-213.

Zhuang, R.Y., L.R. Beuchat and F.J. Angulo. 1995. Fate of Salmonella montevideo on and in raw tomatoes as affected by temperature and treatment with chlorine. Applied Environmental Microbiology 61:2127-2131.

Received: December 2004

Accepted: June 2005 